\title{
The Enforcement of Criminal Laws of Hate Speech in Social Media
}

\section{Feri Vernando Situngkir*) and Siti Rodhiyah Dwi Istinah ${ }^{* *}$}

*) Student of Master of Law, Faculty of Law, Universitas Islam Sultan Agung Semarang, and Police Member E-mail: ferivernando1194@gmail.com

${ }^{* *}$ Faculty of Law, Universitas Islam Sultan Agung Semarang

\begin{abstract}
.
The objectives of this study are as follows: To determine the law enforcement of hate speech crimes in social media. To find out the factors that hinder criminal law enforcement of hate speech in social media. This is to determine the efforts to overcome the obstacles to the enforcement of the hate speech criminal law. This study uses an empirical juridical approach, with descriptive analytical research specifications. The results of this study are law enforcement against hate speech offenders on social media starting from the first stage, namely the police. hate speech perpetrators then the next step is to the prosecutor's office, and the last stage of the trial. Penalties in the form of imprisonment and fines for hate speech offenders are expected to provide a deterrent effect on hate speech criminals on social media. Inhibiting factors, namely, Public Awareness Factors, Security Factors, Law Enforcement Factors. Efforts to overcome obstacles, namely Act No. 11 of 2008 which was later revised to Act No. 19 of 2016, the formation of a special division by the police that specifically handles cyber crime cases, the holding of a cyberpatrol to monitor activities on social media, and the establishment of a cyber agency. national to minimize the spread of negative content on social media, as well as the existence of government services to make it easier for the public to report cyber crime cases.

Keywords: Law Enforcement; Crime; Hate Speech; Social Media; Information and Electronic Transactions.
\end{abstract}

\section{Introduction}

Article 27 paragraph (3) of the ITE Law has been a polemic for years, of course the ITE Law continues to claim victims because the trap can catch easy targets for people who happen to want to inform something they think is not good.

In 2016, after 8 years of rampant ITE Law, finally Act No. 11 of 2008 concerning Electronic Information and Transactions was finally amended by Act No. 19 of 2016 concerning Amendments to Act No. 11 of 2008 concerning Electronic Information and Transactions. Even though for Article 27 paragraph (3) the amendment is only in the Elucidation of Article by Article.

Information and communication technology has also changed human behavior, society and civilization globally. ${ }^{1}$ With the advent of the Internet, there is a new kind of world that has never been known to mankind, a world called the virtual world? The emergence of cyberspace has changed the habits of many people, especially in their lives they are accustomed to using the internet. Starting from changing the way and the way business transactions or banking transactions are carried out using the internet take place in a virtual world called electronic

${ }^{1}$ Suhariyanto, Budi. (2014). Tindak Pidana Teknologi Informasi (Cybercrime). Jakarta: Raja Grafindo Persada. p. 2. 
transactions (electronic transactions or e-commerce), education (electronic education), health (tele-medicine), transportation, industrial tourists, environment, to the entertainment sector.

Hate Speech is an act of spreading hatred and enmity that is SARA (ethnicity, religion, race, and between groups). In the legal sense, hate speech is prohibited speech, behavior, writing, or performance because it can trigger acts of violence and prejudice either from the perpetrator of the statement or the victim of the action. A website that uses or implements hate speech (Hate Speech) is called (Hate Site). Most of these sites use Internet and News Forums to reinforce a particular point of view. ${ }^{2}$

Technological development is one of the factors that can lead to crime, while crime itself has existed and emerged from the beginning of time to the present and the future. The forms of crime that exist are increasingly varied. One thing that should be noted is that crime as a social phenomenon has not yet been taken into account and recognized as a tradition or culture, even though when compared to other existing cultures, the age of crime is certainly older. Crime actually grows and develops in society, there is no crime without society. However much we know about the various evil factors that exist in society, ${ }^{3}$

The objectives of this study are as follows: To determine the law enforcement of hate speech crimes in social media. To find out the factors that hinder criminal law enforcement of hate speech in social media. This is to determine the efforts to overcome the obstacles to the enforcement of the hate speech criminal law.

\section{Research methods}

The approach of this research is juridical empirical in other words, it is a type of sociological legal research and can also be called field research, which examines the applicable legal provisions and what happens in reality in society. ${ }^{4}$ In this research, the method used is a descriptive analysis method. With the object of research on statutory regulations associated with legal theories. Likewise, the law in its implementation in society, which relates to the object of research.The data used in this research is secondary data obtained through library research.

\section{Results and Discussion}

\subsection{Hate Speech Criminal Law Enforcement in Social Media}

Criminal law enforcement is a part of the (criminal) law enforcement mechanism, so punishment, which is usually interpreted as "punishment" is nothing but a deliberately planned "policy process".

The first stage is often called the "in abstracto" punishment stage, while the second and third stages are called the "in concreto" punishment stage. Judging

\footnotetext{
2 Syahdeini, Sutan Remy. (2009). Kejahatan Dan Tindak Pidana Komputer. Jakarta: Pustaka Utama Grafiti. p. 38

${ }^{3}$ Raharjo, Agus. (2002). Cybercrime Pemahaman dan Upaya pencegahan Kejahatan Berteknologi. Bandung: Citra Aditya Bakti. p. 29.

${ }^{4}$ Waluyo, Bambang. (2002). Penelitian Hukum Dalam Praktek. Jakarta: Sinar Grafika. p.15
} 
from a process of criminal law enforcement mechanisms, the three stages are expected to form a link in a chain that is interrelated in one unanimity system. ${ }^{5}$

And for this incident, the reporter as a member of the police reported the incident to be followed up, as referred to in Article 28 paragraph (2) and / or $45 \mathrm{~A}$ paragraph (2) of Law of the Republic of Indonesia Number 19 of 2016 concerning Amendments to Law of the Republic of Indonesia Number 11 of of 2008 regarding Electronic Transaction Information in conjunction with Article 156 a of the Criminal Code.

It was also stated that hate speech (Hate Speech) could be done through various media, including in speech campaign activities; banners or banners; social media networks; delivery of public opinion (demonstration); religious lectures; printed and electronic media and pamphlets. To deal with acts of hate speech so as not to create discrimination, violence, loss of life, and / or social conflicts that are widespread, the necessary measures are handling preventive and repressive actions. ${ }^{6}$

In uncovering cases of cyber crime through social media, investigators have two ways to carry out investigations that are used to find tools and evidence, suspects, determination of tempus and locus delicti, as follows: ${ }^{7}$

- Online method, namely by using a computer with the internet to collect evidence and the perpetrator.

- The online method is to do a computer forensic test to obtain evidence and evidence that is done with computer or conventional technology. ${ }^{8}$

Hate speech criminal law enforcement in social media, namely the perpetrators of posting hate speech of people who share posts containing hate speech should also be convicted in accordance with the provisions of the Law. The law enforcement process against hate speech offenders on social media starts from the first stage, namely the police, in handling police cases putting forward a restorative justice approach, in addition to prevention, one of which is by conducting cyber patrols and counter opinion on social media, the police also take action against hate speech perpetrators then the next stage goes to the prosecutor's office, and the last stage is the trial.

\subsection{Factors that hinder the enforcement of the criminal law of hate speech in social media}

Criminal law enforcement is an attempt to translate and realize the wishes of criminal law into reality, namely criminal law according to Van Hammel is the whole basis and rules adopted by the state in its obligation to uphold the law,

\footnotetext{
${ }^{5}$ Nawawi, Muladi dan Barda. (1992). Bunga Rampai Hukum Pidana. Bandung: Alumni. p. 91

6 Zaldy Kurniawan, Police Role In The Handling Of Hate Speech, Jurnal Daulat Hukum Volume 1 Issue 2, June 2018 ISSN: 2614-560X

7 Timbul Mangaratua Simbolon, Gunarto, Umar Ma'ruf, Kebijakan Hukum Pidana Terhadap Tindak Pidana Penghinaan Atau Pencemaran Nama Baik Melalui Internet Di Indonesia Sebagai Cybercrime, Jurnal Daulat Hukum Vol. 1. No. 1 Maret 2018 ISSN: 2614-560X

${ }^{8}$ Susan, Novri. (2008). Sosiologi Konflik dan Isu-Isu Konflik Kontemporer. Jakarta: Kencana. p. 8
} 
namely by prohibiting what is contrary to the law (On Recht) and impose sorrow (suffering) on those who violate the prohibition. ${ }^{9}$

Law enforcement in the modern state has been described with bureaucratic characteristics, which seem separate from the functions of the police as investigators, prosecutors as public prosecutors, and judges as judges. The three subsystems are a bond within 1 (one) law enforcement system known as a criminal justice system. In accordance with the Indonesian judicial system which adheres to a continental system, the function of the legal bureaucracy subsystem has different duties, powers and responsibilities that prioritizes procedural so that sometimes it pays less attention to the sense of justice than the interests of legal certainty. 10

Referring to the Chief of Police Circular Number: SE / 06 / X / 2015 concerning the Handling of Hate Speech. Because this Circular is an internal regulation that is used as a reference in handling cases of hate speech. In enforcing the law regarding cases of hate speech based on this Circular Letter, there is a division of handling. If the case of hate speech violates the articles contained in the Criminal Code, the case will be handled in the Criminal section (General Criminal). Meanwhile, if the case of hate speech violates articles contained in other laws outside the Criminal Code, for example the ITE Law, the case will be handled in the Crimes (Special Crimes) section.

The defendant was proven to have deliberately spread hatred through online media without rights so as to cause hatred, divisions, and discrediting certain ethnicities. The defendant wrote articles that did not match the facts and uploaded them to social media. The writing cornered certain ethnicities. Uploading these articles can cause and trigger national division by spreading fake news.

Law enforcement officers have carried out their function to enforce the law in accordance with the norms and laws in force in Indonesia. It is certain that law enforcement officials in upholding the law are based on the objectives of law, namely justice, benefit and legal certainty. Must not conflict with each other. In enforcing the law related to hate speech, law enforcement officials such as public prosecutors use the articles contained in the Criminal Code and the Law related to hate speech.

Factors that hinder the enforcement of hate speech criminal law in social media, namely: Public Awareness Factors, where people do not really know what cyber crime is and the types of crimes that exist in it, next is the Security Factor, which makes perpetrators free to commit world crimes. virtual because it is in a hidden place and difficult to trace and equipped with adequate technology, Law Enforcement Factors,

\footnotetext{
${ }^{9}$ Sudarto. (1989). Hukum dan Hukum Pidana. Bandung: Alumni. p. 60

${ }^{10}$ Sunarso, Siswanto. (2005). Wawasan Penegakan Hukum di Indonesia Bandung: Citra Aditya Bakti. p. 135.
} 


\subsection{Efforts to overcome obstacles to criminal law enforcement on hate speech on social media}

The general coverage of UU-ITE includes information and electronic documents, sending and receiving of electronic mails, electronic signatures, electronic certificate, and electronic system operation. ${ }^{11}$

The internet in Indonesia has an important influence on the shape of society. All the convenience of a lifestyle that is given of course continues to have a negative impact on the life of the nation. Crime using the internet has also increased, one of which is online gambling crimes. So that the police can carry out investigations into online gambling crimes, using the Law of the Republic of Indonesia Number 11 of 2008 concerning Electronic Information and Transactions (ITE Law). With the provisions regulating digital evidence and electronic evidence in the ITE Law, this will make it easier for the police to prove and enforce the law against the perpetrators of crimes. ${ }^{12}$

Actions prohibited in Article 28 paragraph (2) of the ITE Law are intentionally and without the right to disseminate information aimed at causing hatred or hostility to certain individuals and / or community groups based on ethnicity, religion, race and intergroup (SARA).

In fact, the purpose of this article is to prevent hostilities, riots, or even divisions based on SARA due to negative, provocative information. The issue of SARA in the view of the community is quite a sensitive issue. Therefore, this article is regulated in a formal offense, and not a material offense.

An example of its application is if someone writes a status in an information social network that contains provocation against a certain ethnic / religion with the intention of inciting the public to hate or anarchy against certain groups, then Article 28 paragraph (2) of the ITE Law can be directly used by Law Enforcement Officials. ("APH") to ensnare the perpetrator who wrote down the status.

The effectiveness of the article can of course be seen from at least two sides, namely regulation and implementation / enforcement (law enforcement). In terms of regulation, the formulation of this article is considered sufficient. Meanwhile, in the aspect of the application / enforcement of the article in question, it certainly depends on each case that occurs or in other words the application of the article is relatively difficult to measure its effectiveness parameters. ${ }^{13}$

PreventionInformation technology crimes need to be balanced with the improvement and development of the criminal law system as a whole, which includes the development of the culture, structure and substance of criminal law.

\footnotetext{
${ }^{11}$ Sri Sumarwani, Tinjauan Yuridis Pemidanaan Cybercrime Dalam Perpektif Hukum Pidana Positif, Jurnal Pembaharuan Hukum Volume I No. 3 September - December 2014 Dosen Fakultas Hukum UNISSULA

12 Farris Nur Sanjaya, Application of Law Information and Electronic Transactions in Crime Investigation of Online Gambling, Jurnal Daulat Hukum Volume 1 No. 2 June 2018 ISSN: 2614-560X, Unissula

13 https://www.hukumonline.com/klinik/detail/ulasan/lt4fb9207f1726f/interprestasi-pasal-28ayat-2-undang-undang-no-11-tahun-2008-tentang-informasi-transaksi-elektronik/
} 
In this case, criminal law policy occupies a strategic position in the development of modern criminal law. ${ }^{14}$

Efforts to overcome the barriers to law enforcement on hate speech in social media include: Act No. 11 of 2008 which was later revised to Act No. 19 of 2016, the formation of a special division by the police that specifically handles cyber crime cases, the holding of a cyberpatrol to monitor activities on social media, to the formation of a national cyber agency to minimize the spread of negative content on social media, as well as the existence of government services to make it easier for the public to report cyber crime cases.

\section{Closing}

Hate speech criminal law enforcement in social media, namely the perpetrators of posting hate speech of people who share posts containing hate speech should also be convicted in accordance with the provisions of the Law. The law enforcement process against hate speech offenders on social media starts from the first stage, namely the police, in handling police cases putting forward a restorative justice approach, in addition to prevention, one of which is by conducting cyber patrols and counter opinion on social media, the police also take action against hate speech perpetrators then the next stage goes to the prosecutor's office, and the last stage is the trial. The factors that hinder the enforcement of hate speech criminal law in social media, namely, the Public Awareness Factor, where people do not really know what cyber crime is and the types of crimes that exist in it, then the Security Factor, which makes perpetrators free to commit world crimes. virtual because it is in a hidden place and difficult to trace and equipped with adequate technology, Law Enforcement Factors. Efforts to overcome obstacles to law enforcement on hate speech in social media, namely Act No. 11 of 2008 which was later revised to Act No. 19 of 2016, the formation of a special division by the police that specifically handles cases of cyber crime, the holding of a cyberpatrol to monitor activities on social media, to the establishment of a national cyber agency to minimize the spread of negative content on social media, as well as government services to make it easier for the public to report cyber crime cases.

Conduct training for law enforcers on ITE and hate speech in order to make it easier for law enforcers to handle cases of hate speech on social media and so that the ability of law enforcers is not left behind by the rapidly developing crime mode in the ITE field. Providing education to the public about what hate speech is, the dangers of hate speech and the threat of punishment for anyone who makes hate speech on social media so that people do not easily believe and are provoked by information without knowing the truth of the information spread on social media, and so that society is wiser in using social madia.

\footnotetext{
${ }^{14}$ Laksana, Andri Winjaya. (2019). Pemidanaan Cybercrime Dalam Perspektif Hukum Pidana Positif Fakultas Hukum Unissula Jurnal Hukum Unissula Vol.35 No.1.
} 


\section{References}

\section{Journals:}

[1] Farris Nur Sanjaya, Application of Law Information and Electronic Transactions in Crime Investigation of Online Gambling, Jurnal Daulat Hukum Volume 1 No. 2 June 2018 ISSN: 2614-560X, Unissula

[2] Laksana, Andri Winjaya. (2019). Pemidanaan Cybercrime Dalam Perspektif Hukum Pidana Positif Fakultas Hukum Unissula Jurnal Hukum Unissula Vol.35 No.1.

[3] Sumarwani, Tinjauan Yuridis Pemidanaan Cybercrime Dalam Perpektif Hukum Pidana Positif, Jurnal Pembaharuan Hukum Volume I No. 3 September December 2014 Dosen Fakultas Hukum UNISSULA

[4] Timbul Mangaratua Simbolon, Gunarto, Umar Ma'ruf, Kebijakan Hukum Pidana Terhadap Tindak Pidana Penghinaan Atau Pencemaran Nama Baik Melalui Internet Di Indonesia Sebagai Cybercrime, Jurnal Daulat Hukum Vol. 1. No. 1 Maret 2018 ISSN: 2614-560X

[5] Zaldy Kurniawan, Police Role In The Handling Of Hate Speech, Jurnal Daulat Hukum Volume 1 Issue 2, June 2018 ISSN: 2614-560X

\section{Books:}

[1] Nawawi, Muladi dan Barda. (1992). Bunga Rampai Hukum Pidana. Bandung: Alumni.

[2] Raharjo, Agus. (2002). Cybercrime Pemahaman dan Upaya pencegahan Kejahatan Berteknologi. Bandung: Citra Aditya Bakti.

[3] Sudarto. (1989). Hukum dan Hukum Pidana. Bandung: Alumni.

[4] Suhariyanto, Budi. (2014). Tindak Pidana Teknologi Informasi (Cybercrime). Jakarta: Raja Grafindo Persada.

[5] Sunarso, Siswanto. (2005). Wawasan Penegakan Hukum di Indonesia Bandung: Citra Aditya Bakti.

[6] Susan, Novri. (2008). Sosiologi Konflik dan Isu-Isu Konflik Kontemporer. Jakarta: Kencana.

[7] Syahdeini, Sutan Remy. (2009). Kejahatan Dan Tindak Pidana Komputer. Jakarta: Pustaka Utama Grafiti.

[8] Waluyo, Bambang. (2002). Penelitian Hukum Dalam Praktek. Jakarta: Sinar Grafika.

\section{Internet}

[1] https://www.hukumonline.com/klinik/detail/ulasan/lt4fb9207f1726f/inter prestasi-pasal-28-ayat-2-undang-undang-no-11-tahun-2008-tentanginformasi-transaksi-elektronik/ 